\title{
MAGNETIC RESONANCE IMAGING FOR PREDICTING PERSONALIZED ANTITUMOR NANOMEDICINE EFFICACY
} \author{
Majouga $\mathrm{AG}^{1,2,5}$, Chekhonin VP ${ }^{3}$ \\ ${ }^{1}$ Biomedical Nanomaterials Laboratory, National University of Science and Technology MISIS, Moscow \\ 2 Tissue-specific Ligands Research Laboratory, Faculty of Chemistry, \\ Lomonosov Moscow State University, Moscow \\ ${ }^{3}$ Pirogov Russian National Research Medical University, Moscow \\ ${ }^{4}$ Lebedev Physical Institute, Russian Academy of Sciences, Moscow \\ ${ }^{5}$ Mendeleyev University of Chemical Technology of Russia, Moscow
}

Naumenko VA ${ }^{1} \otimes$, Garanina $\mathrm{AS}^{1,2}$, Vodopyanov $\mathrm{SS}^{1}$, Nikitin $\mathrm{AA}^{1,2}$, Prelovskaya $\mathrm{AO}^{1}$, Demikhov $\mathrm{El}^{4}$, Abakumov $\mathrm{MA}^{1,3}$

\begin{abstract}
Magnetic resonance imaging (MRI) is widely used to diagnose cancer and study patterns and effectiveness of nanocarrier delivery of anticancer drugs. Accumulation of nanoparticles in a tumor varies widely in a given population; it is also highly dependent on biological factors, which remain largely unstudied. In recent years, there was developed a hypothesis that suggests that MRI can be used to predict response to nanoformulations-based anticancer therapy since it provides data on accumulation of MRI contrast agents in the tumor. Pilot tests prove feasibility of the approach based on this hypothesis, however, there is a number of conceptual and technical problems and limitations that hamper its introduction into the routine clinical practice. This article discusses the advantages and disadvantages of methods to stratify tumors by level of nanoparticles accumulation. Further research in this field would facilitate development of effective algorithms of personalized treatment with anticancer drugs delivered by nanoparticles.
\end{abstract}

Keywords: anticancer therapy, magnetic resonance imaging, nanoparticles, personalized medicine

Funding: the study was financially supported by the Ministry of Education and Science of the Russian Federation under the Federal Targeted Programme for Research and Development in Priority Areas of Development of the Russian Scientific and Technological Complex for 2014-2020, Agreement \#14.575.21.0147 of 27.09.2017 (Agreement ID RFMEFI57517X0147)

Correspondence should be addressed: Victor A. Naumenko

Leninsky 4, Moscow, 119049; naumenko.vict@gmail.com

Received: 30.08.2018 Accepted: 25.09.2018

DOI: $10.24075 /$ brsmu.2018.086

\section{МАГНИТНО-РЕЗОНАНСНАЯ ТОМОГРАФИЯ ДЛЯ ПЕРСОНАЛИЗИРОВАННОЙ ОЦЕНКИ И ПРОГНОЗИРОВАНИЯ ЭФФЕКТИВНОСТИ ДОСТАВКИ НАНОФОРМУЛЯЦИЙ ПРОТИВООПУХОЛЕВЫХ ПРЕПАРАТОВ}

В. А. Науменко ${ }^{1 凶}$, А. С. Гаранина ${ }^{1,2}$, С. С. Водопьянов ${ }^{1}$, А. А. Никитин ${ }^{1,2}$, А. О. Преловская ${ }^{1}$, Е. И. Демихов ${ }^{4}$, М. А. Абакумов ${ }^{1,3}$, А. Г. Мажуга ${ }^{1,2,5}$, В. П. Чехонин ${ }^{3}$

1 Лаборатория биомедицинских наноматериалов, Национальный исследовательский технологический университет «МИСиС», Москва

2 Научно-исследовательская лаборатория тканеспецифических лигандов, Химический факультет,

Московский государственный университет имени М.В.Ломоносова, Москва

з Российский национальный исследовательский медицинский университет имени Н. И. Пирогова, Москва

${ }^{4}$ Физический институт имени П. Н. Лебедева Российской академии наук, Москва

${ }_{5}^{5}$ Российский химико-технологический университет имени Д. И. Менделеева, Москва

\begin{abstract}
Магнитно-резонансная томография (МРТ) широко используется для диагностики онкологических заболеваний, а также для исследования доставки препаратов на магнитных наноносителях. Накопление наночастиц в опухоли высоко вариабельно в популяции и зависит от биологических факторов, которые во многом остаются неизученными. В последние годы было высказано предположение о возможности использования МРТ для предсказания ответа на терапию наноформулированными препаратами на основе скрининговых данных о накоплении в опухоли магнитноконтрастных диагностикумов. Несмотря на то что пилотные испытания указывают на принципиальную возможность предложенного подхода, существует ряд концептуальных проблем и технических ограничений для внедрения технологии в клинику. В статье обсуждаются преимущества и недостатки методов, позволяющих стратифицировать опухоли по степени накопления наночастиц. Дальнейшие исследования в данной области позволят разработать эффективные алгоритмы индивидуального лечения противоопухолевыми препаратами, доставляемыми на наночастицах.
\end{abstract}

Ключевые слова: противоопухолевая терапия, магнитно-резонансная томография, наночастицы, персонализированная медицина

Финансирование: работа выполнена при финансовой поддержке Министерства образования и науки РФ в рамках ФЦП «Исследования и разработки по приоритетным направлениям развития научно-технологического комплекса России на 2014-2020 годы», соглашение от 27.09.2017 г. № 14.575.21.0147 (уникальный идентификатор соглашения RFMEFI57517X0147)

$\bowtie$ Для корреспонденции: Виктор Алексеевич Науменко

Ленинский проспект, д. 4, г. Москва, 119049; naumenko.vict@gmail.com

Статья получена: 30.08.2018 Статья принята к печати: 25.09.2018

DOI: $10.24075 /$ vrgmu.2018.086 
Oncological diseases are a major cause of death, disabilities, poor quality of life of the patients and the associated economic loss. Traditional cancer treatment methods, which include radical surgery, chemo and radiation therapy, are not highly effective, which makes the search for new therapeutic approaches to the problem an urgent task. Current cancer diagnostics and treatment trends seen worldwide are 1) introduction of the highly sensitive diagnostic methods, 2) development of the new drugs and methods to deliver them into tumors; 3) transition to personalized medicine.

All these trends and the underlying concepts benefit from the use of nanoparticles (NPs) [1]. Firstly, magnetic NPs (MNPs) allow using MRI for cancer detection. Secondly, there is a number of nanoformulations capable of delivering chemotherapeutic drugs to the tumor (liposomes, polymeric micelles, albuminbased NPs) that have already been approved for clinical use. Diagnostic and therapeutic potential of NPs enables their use in the context of personalized prediction of treatment efficacy. Picture 1 depicts the main idea of using MRI in the personalized MNP-based therapeutic algorithms. Screening tumors to register accumulation of nanocarriers therein aides the selection of the appropriate treatment strategy. MRI-assisted estimation of the level of contrast agents accumulation in a tumor allows predicting accumulation of the selected anticancer drug. The hypothesis is that the tumors with higher levels of contrast agent accumulation will respond better to MNP-based therapy.

There is a number of reasons behind the need for personalized treatment effectiveness prediction. Firstly, nanoformulations should be prescribed when the EPR-effect (higher blood vessels permeability and weaker lymphatic drainage) ensures sufficient drug accumulation in the tumor. Otherwise, nanoformulationsbased therapy should be preceded by treatments increasing permeability of the tumor's vessels, e.g., local vasodilation through heating, injecting nitric oxide, prostaglandins (Fig. 1). Increasing arterial pressure with the help of angiotensin II or breaking the tumor matrix with collagenase can also facilitate delivery of drugs to the tumor [2]. Yet another method to counter insufficient accumulation of anticancer agent in the tumor is to deliver it on NPs conjugated with cancer specific ligands $[3,4]$. Secondly, there are purely economic reasons to pick the latter when considering nanoformulations and regular anticancer drugs: for example, the cost of $20 \mathrm{mg}$ doxorubicin is 540 rubles while that of Doxil is 42,300 rubles.

\section{Methods and strategies for individual prognosis of nanodrug delivery to tumors}

Currently, there are no routinely applied clinical algorithms allowing to evaluate the EPR-effect and the related efficacy of nanoformulated drug in a given patient. The issue is being addressed, however: a number of research teams conduct respective preclinical and clinical studies.

One of such studies examined the possibility of using magnetic particles (ferumoxytol) to estimate the efficacy of treatment with paclitaxel nanoformulation. The animals (this was an animal model study) were divided into groups by the MRIregistered level of EPR effect intensity; subsequent treatment with nanoformulated drug showed significant differences in the tumor cells death rates and response to therapy among those groups [5]. In 2017, researchers published the first results of a clinical study that implied using MRI to register the magnetic nanoparticles (ferumoxytol) delivery data and subsequently evaluate the effectiveness of treatment of 13 solid tumor patients with irinotecan nanoformulation. High ferumoxytol accumulation levels (within 1 to 24 hours) were shown to correlate with the therapy-induced tumor involution [6]. The suggested approach, however, has a major drawback: the difference in physical properties of diagnostic and therapeutic NPs was significant; their sizes, in particular, were $23 \mathrm{~nm}$ and $110 \mathrm{~nm}$, respectively. It is well-known that delivery of NPs to a tumor depends on their hydrodynamic size: the smaller the particle, the more effective its extravasation and penetration into the tumor tissues [7]. Intravital microscopy conducted to determine pharmacokinetics of ferumoxytol and PGLA-PEG revealed the differences in speed and patterns of accumulation for these two NP types [5].

Mammography allowed predicting efficacy of breast cancer treatment in rats with doxorubicin incapsulated into $100 \mathrm{~nm}$ iodine-containing liposomes [8]. Contrast agent accumulation data was used to identify animals that were supposed to respond well to anticancer therapy, a prediction that fulfilled later. However, the efficacy of this approach was shown only in one tumor model. The method proposed is based on X-ray

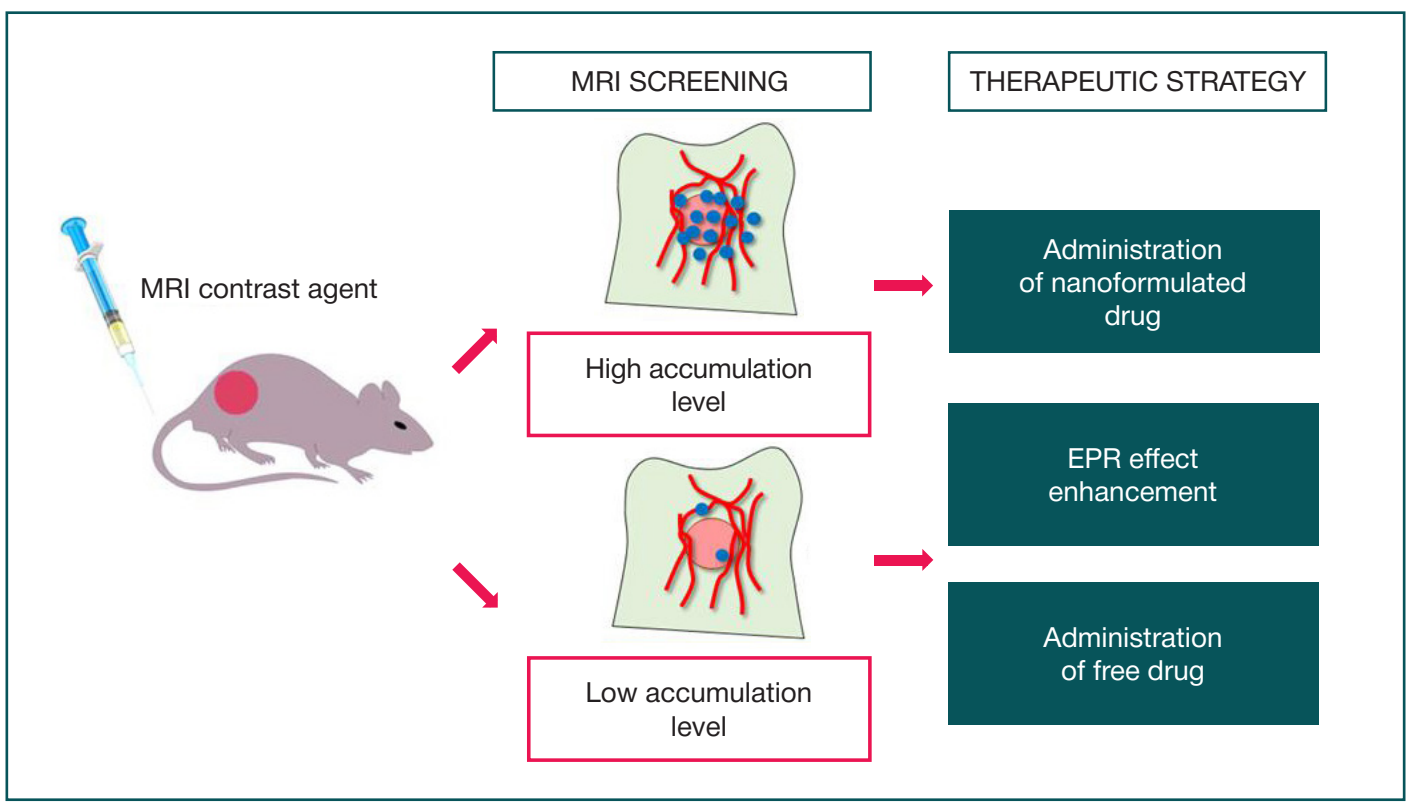

Fig. 1. Algorithm of personalized evaluation and antitumor nanodrug delivery efficacy prediction in an animal mode 
examination, which is less sensitive and safe than MRI, the factors that limit its adoption in the routine clinical practice.

Another interesting clinical study investigated the correlation between accumulation of doxorubicin-containing ${ }^{64} \mathrm{Cu}$-labeled HER2-directed PEG-modified liposomes in tumor and efficacy of therapy in 19 patients with HER2-positive metastatic breast cancer. Positron emission tomography and computed tomography was applied to detect the radioactively labeled NPs. The researchers found a positive correlation between the high level of accumulation of labeled NPs and positive response to therapy [9]. The original aim of this study was to evaluate the effectiveness of breast cancer treatment with a combination of liposomal doxorubicin, trastuzumab and cyclophosphamide. In this connection, it is difficult to interpret contribution of the concomitant factors to the data obtained. Besides, the study focused on one tumor type only, so further investigations are needed to arrive at a valid conclusion.

A series of studies that researched doxorubicin nanoformulations labeled with radioactive technetium yielded similar data. In an animal model, researchers revealed a correlation between intensity of signal from the tumor (registered with the help of a single photon emission computed tomography) and accumulation of the drug in extracted tumors [10]. The efficacy of this approach was confirmed in a clinical trial, where ${ }^{(99 \mathrm{~m})}$ Tc-labeled liposomal doxorubicin was administered to 35 patients with mesothelioma. There was a correlation between the level of the drug accumulation in tumors and antitumor response [11]. However, due to safety concerns radioactive materials are not widely used in clinics, which limits applicability of the approach.

Gene, protein and cellular predictive markers were suggested as alternatives to the in vivo visualization methods used to assess the EPR effect. For example, liposome accumulation can be predicted based on the MMP9 (metalloproteinase 9) to TIMP1 (metaloproteinase 1 tissue inhibitor) ratio $[12,13]$. In addition, growth factors of endothelial cells (VEGFA) and fibroblasts (FGF2), interleukins (IL6, IL8), peptides (endostatin), as well as endothelial cells and their precursors [14, 15] are being researched as potential EPR markers.

\section{MRI in personalized MNP-based cancer therapy: problems and prospects}

In our opinion, the approaches based on in vivo imaging, confirmed in animal models and being researched in the context of clinical trials, are the most promising. Unlike biomarkers analysis, these non-invasive methods make use of equipment and contrast agents available in the majority of hospitals. Besides, compared to the radiological and X-ray examination methods, MRI is safer and more widely spread. However, there is a number of conceptual problems and technical constraints that hamper development of a technology to evaluate and predict the effectiveness of nanodrug delivery in a given patient, namely:

1) different properties of the NPs used as diagnostic and therapeutic agents [5];

2) lack of data on the potential effect the first (diagnostic) dose has on biodistribution of the second (therapeutic) dose;

3) lack of data describing the time-related change, if any, of the EPR effect in the same tumor (the change that may determine differences in accumulation of the first and second NP doses);

4) retrospective character of the majority of studies delivering the data, as well as their focus on one model of tumor only and small samples;
5) lack of studies where investigating the correlation between EPR effect and antitumor response to nanodrugs is a primary goal and there are no concominant factors such as combination therapy

A comprehensive assessment of the EPR effect heterogeneity and its determinants requires studying different tumor models (allografts and xenografts, orthotopic and heterotopic) and types. The analysis of differences in NPs accumulation in different animals within the same tumor model allows intragroup heterogeneity assessment. We have recently performed a number of experiments with MNPs and the results clearly demonstrate that MRI can be used to assess the EPR effect in different tumor models and various animals (Fig. 2). Based on the data obtained, it is possible to rank animals into prognostic groups and subsequently assess therapeutic efficacy of the nanodrugs. Heterogeneity of the NPs accumulation can also be associated with evolution of tumor vessels and changes in the tissues architecture, which dictates the need for studying EPR effect at the different stages of tumor growth.

An important step in the process of introducing personalized nanodrug therapy to routine clinical practice is comparison of accumulation of the first and the second doses of NPs. Firstly, physicochemical properties of diagnostic and therapeutic NPs should be the same. Secondly, there is a possibility that the first dose affects subsequent NP administrations. For example, earlier studies have shown that first intravenous injection of

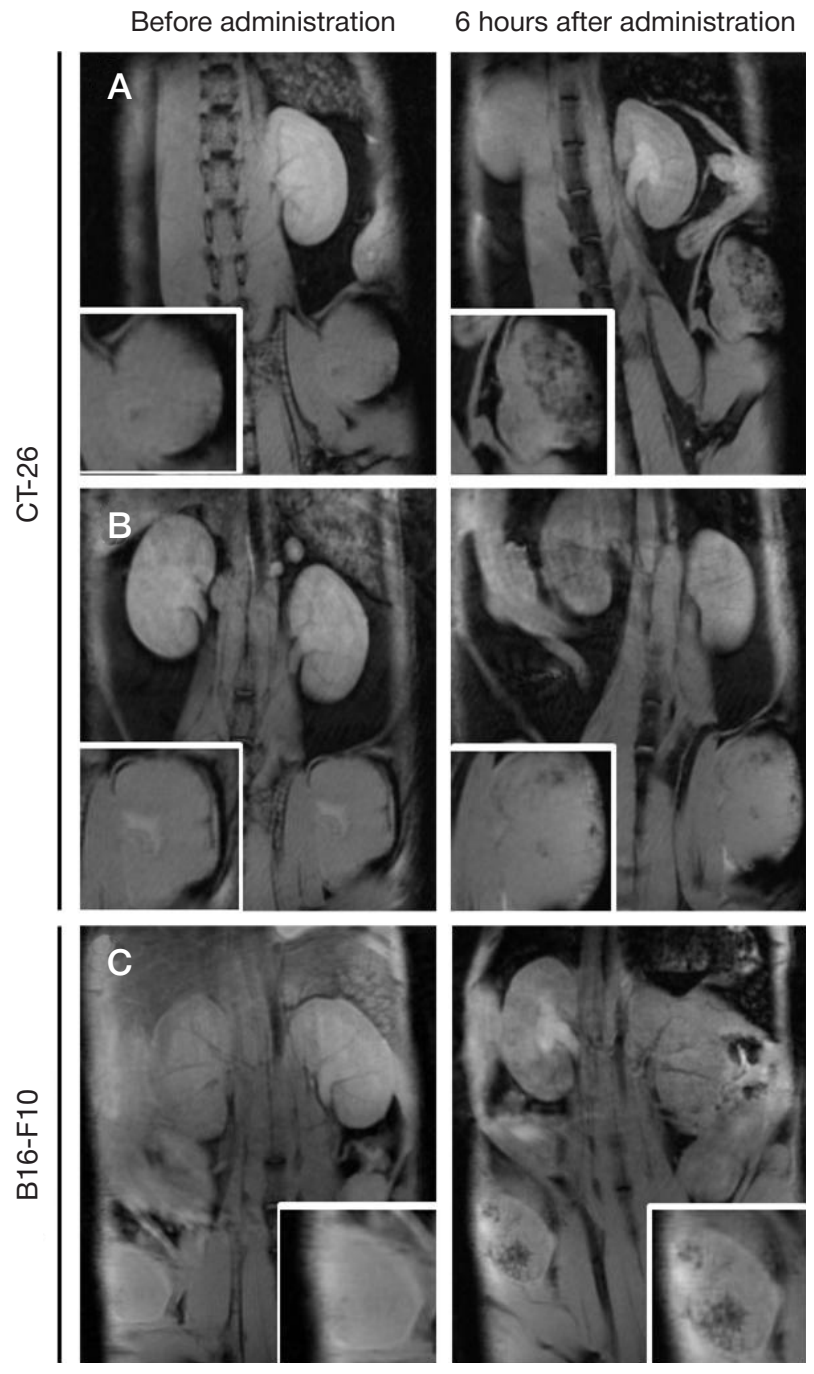

Fig. 2. EPR effect heterogeneity: intragroup (A-B); between different tumor models $(\mathbf{A}-\mathbf{C})$ 
oncolytic viruses activates subsequent doses capturing by monocytes/macrophages. The same phenomenon may be peculiar to multiple dosing of NPs. Finally, the EPR effect can change dynamically within the same tumor, a factor that should be taken into account when assessing predictive power of the first dose. NPs conjugated with different dyes can be used to model biodistribution of the two doses. Intravital microscopy allows evaluating extravasation, diffusion and accumulation dynamics of the first and the second doses, as well as target cells in the tumor microenvironment. A combination of MRI and intravital microscopy also shows promise. The first method allows screening and ranking tumors into high and low NP accumulation groups, while the second enables investigation of the cellular mechanisms defining the differences in the EPR effect.

\section{CONCLUSIONS}

The concept of applying non-invasive methods and MNPs to develop individual therapeutic algorithms in oncology seems promising and realistic. The use of novel methods studying EPR determinants, as well as validation of MRI as a screening method in animal models will facilitate introduction of the personalized cancer nanotherapy technology to the routine clinical practice.

\section{References}

1. Shi $J$ et al. Cancer nanomedicine: progress, challenges and opportunities. Nat Rev Cancer. NIH Public Access, 2017; 17 (1): 20-37.

2. Prabhakar $U$ et al. Challenges and key considerations of the enhanced permeability and retention effect for nanomedicine drug delivery in oncology. Cancer Res. 2013; 73 (8): 2412-17.

3. Davis ME et al. Evidence of RNAi in humans from systemically administered siRNA via targeted nanoparticles. Nature. 2010; 464 (7291): 1067-70

4. Hrkach $\mathrm{J}$ et al. Preclinical development and clinical translation of a PSMA-targeted docetaxel nanoparticle with a differentiated pharmacological profile. Sci Transl Med. 2012; 4 (128): 128ra39.

5. Miller MA et al. Predicting therapeutic nanomedicine efficacy using a companion magnetic resonance imaging nanoparticle. Sci Transl Med. 2015; 7 (314): 314ra183.

6. Ramanathan RK et al. Correlation between Ferumoxytol Uptake in Tumor Lesions by MRI and Response to Nanoliposomal Irinotecan in Patients with Advanced Solid Tumors: A Pilot Study. Clin Cancer Res. 2017; 23 (14): 3638-48.

7. Wilhelm $\mathrm{S}$ et al. Analysis of nanoparticle delivery to tumours. Nat Rev Mater. 2016; 1 (5): 16014.

8. Karathanasis $\mathrm{E}$ et al. Imaging nanoprobe for prediction of outcome of nanoparticle chemotherapy by using mammography. Radiology. 2009; 250 (2): 398-406.

\section{Литература}

1. Shi $J$ et al. Cancer nanomedicine: progress, challenges and opportunities. Nat Rev Cancer. NIH Public Access, 2017; 17 (1): 20-37.

2. Prabhakar $U$ et al. Challenges and key considerations of the enhanced permeability and retention effect for nanomedicine drug delivery in oncology. Cancer Res. 2013; 73 (8): 2412-17.

3. Davis ME et al. Evidence of RNAi in humans from systemically administered siRNA via targeted nanoparticles. Nature. 2010; 464 (7291): 1067-70

4. Hrkach $\mathrm{J}$ et al. Preclinical development and clinical translation of a PSMA-targeted docetaxel nanoparticle with a differentiated pharmacological profile. Sci Transl Med. 2012; 4 (128): 128ra39.

5. Miller MA et al. Predicting therapeutic nanomedicine efficacy using a companion magnetic resonance imaging nanoparticle. Sci Transl Med. 2015; 7 (314): 314ra183.

6. Ramanathan RK et al. Correlation between Ferumoxytol Uptake in Tumor Lesions by MRI and Response to Nanoliposomal Irinotecan in Patients with Advanced Solid Tumors: A Pilot Study. Clin Cancer Res. 2017; 23 (14): 3638-48.

7. Wilhelm $\mathrm{S}$ et al. Analysis of nanoparticle delivery to tumours. Nat Rev Mater. 2016; 1 (5): 16014.

8. Karathanasis $\mathrm{E}$ et al. Imaging nanoprobe for prediction of outcome of nanoparticle chemotherapy by using mammography. Radiology. 2009; 250 (2): 398-406.

9. Lee $\mathrm{H}$ et al. 64Cu-MM-302 Positron Emission Tomography Quantifies Variability of Enhanced Permeability and Retention of Nanoparticles in Relation to Treatment Response in Patients with Metastatic Breast Cancer. Clin Cancer Res. 2017; 23 (15): 4190-02.

10. Head HW et al. Combination radiofrequency ablation and intravenous radiolabeled liposomal Doxorubicin: imaging and quantification of increased drug delivery to tumors. Radiology. 2010; 255 (2): 405-14.

11. Arrieta $\mathrm{O}$ et al. A phase II trial of prolonged, continuous infusion of low-dose gemcitabine plus cisplatin in patients with advanced malignant pleural mesothelioma. Cancer Chemother Pharmacol. 2014; 73 (5): 975-82.

12. Yokoi $\mathrm{K}$ et al. Capillary-Wall Collagen as a Biophysical Marker of Nanotherapeutic Permeability into the Tumor Microenvironment. Cancer Res. 2014; 74 (16): 4239-46.

13. Yokoi $\mathrm{K}$ et al. Serum biomarkers for personalization of nanotherapeutics-based therapy in different tumor and organ microenvironments. Cancer Lett. 2014; 345 (1): 48-55.

14. Sessa $\mathrm{C}$ et al. Biomarkers of angiogenesis for the development of antiangiogenic therapies in oncology: tools or decorations? Nat Clin Pract Oncol. 2008; 5 (7): 378-91.

15. Sherwood LM, Parris EE, Folkman J. Tumor Angiogenesis: Therapeutic Implications. N Engl J Med. 1971; 285 (21): 1182-6. 